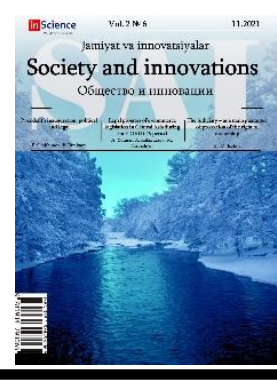

\title{
The influence of the information space on the spiritual existence of a person
}

\section{Said NOROV 1 \\ Samarkand State Institute of Architecture and Construction}

\begin{tabular}{l} 
ARTICLE INFO \\
\hline Article history: \\
Received October 2021 \\
Received in revised form \\
15 October 2021 \\
Accepted 15 November 2021 \\
Available online \\
25 December 2021 \\
\\
\hline Keywords: \\
globalization, \\
moral values, \\
information society, \\
virtual world, \\
spirituality, \\
social institutions.
\end{tabular}

\begin{abstract}
This article describes the spiritual image of a person in the information space. The system of factors that play a key role in the formation of a person's worldview is analyzed and considered. Special attention is paid to the values of the inner development of a person living in modern society. His inner motives, personal values, that is, the main, important, decisive factor in a person's life.

2181-1415/@ 2021 in Science LLC.

DOI: https://doi.org/10.47689/2181-1415-vol2-iss11/S-pp35-39

This is an open access article under the Attribution 4.0 International (CC BY 4.0) license (https://creativecommons.org/licenses/by/4.0/deed.ru)
\end{abstract}

\section{Axborot jamiyatining shaxsning ma'naviy hayotiga ta'siri}

\section{Kalit so'zlar:}

globallashuv,

axloqiy qadriyat,

axborot jamiyati,

virtual olam,

ma'naviyat.
ANNOTATSIYA

Ushbu maqolada axborot jamiyatidagi insonning ruhiy qiyofasi haqida so'z boradi. Insonning dunyoqarashini shakllantirishda asosiy rol o'ynaydigan omillar tizimiga uning hayoti, ichki motivlariga, qadriyat mezoni bo'lmish shaxs qadriga, ya'ni inson hayotidagi asosiy, muhim, hal qiluvchi narsalarga alohida e'tibor beriladi.

\footnotetext{
${ }^{1}$ Associate Professor of the Department of Social Sciences, Candidate of Philosophical Sciences, Samarkand State Institute of Architecture and Construction. Samarkand, Uzbekistan.
} 


\section{Влияние информационного пространства на духовное существование человека}

\author{
Ключевые слова: \\ глобализация, \\ моральные ценности, \\ информационное \\ общество, \\ виртуальный мир, \\ духовность, \\ социальные институты.
}

АННОТАЦИЯ

В данной статье, описывается духовный образ человека в
информационном пространстве. Анализируются и
рассматривается система факторов, играющих ключевую
роль в формировании мировоззрения человека. Особое
внимание, уделяется ценностям внутреннего развития
человека, живущего в современном обществе. Его
внутренним мотивам, ценностям личности, то есть
основным, важным, решающим факторам в жизни человека.

\section{INTRODUCTION}

Before talking about the information society and its impact on the spiritual existence of a person, we briefly describe the concepts of information and information society. "Information from the Latin word informātiō means clarification" [3; 402]. "This concept is one of the most important in science, it means the essence of some evidence, knowledge, etc". [8; 72]. Information is data about things and events, their causes, content and consequences. It is also a means of influencing a person spiritually and ideologically. "Information becomes a powerful tool that affects the human mind in different ways, turning human life and fate in one direction or another, sometimes negative and sometimes positive" [7; 4]. "Information is an important part of spiritual self-organization. Memory, action program, self-organization process, communication and other complex biosocial events cannot occur without information" [6; 5].

A person always works with information in the process of assimilation of the being that surrounds him. Information allows a person to have an idea of what is happening, have information, correctly assess the process, correctly direct their actions and make the right decisions. With the help of information, we expand our knowledge. Today, information has become such a powerful tool that anyone with more recent and relevant information on a particular issue will have an edge over others. That is why today the society in which we live and work is called the information society.

\section{METHODS}

Expanding the scope of information in society, increasing the flow of information gave rise to the concept of an information society. "An informed society is a concept that means that socio-economic development depends primarily on the preparation, processing, storage and transmission of information to members of society" [9; 4]. Recognized by the scientific community as an information society, this society is "a very intense and difficult period, which is radically different from the times that humanity has ever lived and experienced" [10; 190]. This society is characterized by an extremely fast pace of movement, change and development. "The peculiarity of the modern era is reflected in the fact that the social kaleidoscope is paradoxically unbalanced; changes have become the main feature of our time. The transformation of social institutions, changes in the social and cultural environment in which a person lives and parallel changes in the perception of nature occur at lightning speed" [3; 4]. These views suggest that information is the basis for change, instability and imbalance in society. "The rapid exchange and 
change of information about a specific event also leads to changes in all respects" [1; 165$]$. Sudden changes, on the other hand, undermine stability and cause the system to lose balance, since movement, variability, and transition from one state to another is the cause of the emergence and existence of instability.

The social environment in which we live is an open system that is complex and consists of microsystems. Its impact on a person occurs through the environment that directly surrounds the person. The social environment and its microsystems are the main source of information that a person receives. "Human creativity is based on the correct choice of the necessary information. The selection of valuable information increases human potential. The interaction of the microenvironment and the social environment occurs through the exchange of information in the system "person - microenvironment social environment" $[2 ; 68]$.

\section{RESULTS}

The excessive flow and amount of information requires a lot of attention to process this information. For this reason, the penetration of information technologies, telecommunications and computer technologies into human life is an integral part of the information society. One of the greatest influences of the information society on human spiritual existence is the growing role of information technology in human life. Information technology, television and computers penetrate our lives so quickly that managing this process becomes a difficult task. Computer tools have been connecting people since childhood, keeping them away from books, friends, theater, museums and nature. This, in turn, negatively affects the activity of a person with people. In addition, these factors negatively affect the human psyche, self-control, self-expression. For example, the process of playing on a computer is so addictive that even a small child or adult finds it difficult to get distracted and get up. According to psychologists, computer games turn a person into a closed, trapped creature. Excessive indulgence in computer games and other functions of these tools can lead a person away from the real world into the virtual one. This process negatively affects the socialization of people, that is, in communication and interaction between people. Live communication between people is often replaced by electronic communication, various social sites, and e-mail. On the one hand, this facilitates the process of communication between people, on the other, it leads to fraud in relationships between people, the emergence of false relationships.

\section{DISCUSSION}

"In the reflexive analysis of information, the human intellect undergoes the process of self-awareness, self-assessment within the framework of values, which leads to a change in the criteria of values, the dimension of life principles in a person" [5; 44]. Any knowledge in human life is based on information. In the process of cognition, a person becomes self-aware and transforming. This process is the process of development of the human spiritual world, in which the inner, spiritual world of man passes from one instrument to another. The positive, solid basis of the information received makes the process of development in the spiritual world of a person move in a progressive direction, lead him to perfection. Conversely, if the information received is unhealthy, false, which serves certain malicious purposes, a change in a person's spiritual existence can lead to regressive, even aggressive, behavior.

Another influence of the information society on the spiritual existence of a person is that in such a society the criterion of values is rapidly changing. A person's self-awareness is closely related to his or her self-esteem within the values that exist in society. "The 
criterion of values is a set of circumstances, requirements and procedures that determine a person, his activities, lifestyle, beliefs, the meaning of life" [8; 72]. The value system, measurement, plays an extremely important, leading role in human life and activity. It is on the criteria of values that a person's attitude to the environment, society, people and himself is formed.

\section{CONCLUSION}

The system of factors that play a key role in the formation of a person's worldview, life, internal motives, is a criterion of values, that is, a person's assessment of what is the main, important, decisive aspect of his life. In our opinion, another influence of the information society on the spiritual life of people is that it has changed the measurement of values. For example, Western social relations, egocentrism, characteristic of Western people, are also included in our society. In the East, values such as teamwork, serving the interests of the majority, and establishing one's own lifestyle in accordance with the opinions of others have always been a priority. But recently, more and more people have appeared in society, in the life of young people, who express their life principles, their way of life through the prism of their own interests, placing themselves at the center of their lives. This egocentric way of life is one of the products of globalization and the information society and does not meet the lifestyle criteria and our values of the peoples of the East.

\section{REFERENCES:}

1. Rizaev I.I. (2019). Evolutionary mechanisms of self-organization of the social system. Scientific Bulletin of Namangan State University, 1(9), 81-86.

2. Rizaev I.I. (2019). The structure of the social system as the basis for the selforganization of society. Scientific Bulletin of Namangan State University, 1(7), 190-195.

3. Ризаев И.И. (2020). Общество как самоорганизующаяся система. Рациональное природопользование-основа устойчивого развития, 520-525.

4. Ризаев И.И. Синергетический подход к самоорганизации социальных систем. Редакционная коллегия, 294.

5. Ризаев И.И. Society as a self-organizing system. Редакционная коллегия, 520.

6. Imomalievich R.I. (2020). Synergetic interpretation of society development. International Engineering Journal For Research \& Development, 5(3), 5-5.

7. Alikulov S.A., \& Rizaev I.I. (2020). Methodological problems of research of social systems. Theoretical \& Applied Science, (2), 717-720.

8. Rizaev I., Ganiev K., \& Alikulov H. (2020). Evolution of the Social System: From Chaos to Order. TEST Engineering \& Management, 83, 27362-27366.

9. Rizaev Ilhom. (2021). Liberalization of the social system: constructive and destructive aspects. TRANS Asian Journal of Marketing \& Management Research (TAJMMR), Vol 10, Issue 4, Article 8.

10. Alikulov X., Haqqulov N.Q. Spiritual maturity and philosophical thinking dependence of development // ISJ Theoretical \& Applied Science 04(84) 2020. Pages: 164-167.

11. Хаққулов Н.Қ. Сиддиқий-Ажзий маърифатпарварлик қарашларида миллий толерантлик масаласи // НамДУ илмий ахборотномаси - Научный вестник НамГУ. - 2020. - №10. - Б. 296-302.

12. Xaqqulov N.Q. Perfect generation - personality of private education and humanity facilities // «МИРОВАЯ НАУКА» международное электронное научнопрактическое периодическое издание. - 2019. - №2(23). - С. 62-63. 
13. Сафаров А.И., Хаккулов Н.К. Свойственные качества совершенному человеку в суфизме // Современная наука как социально-политический фактор развития государства: материалы международной научно практической конференции (10 мая 2019г., Москва) Отв. ред. Зарайский А.А. - Издательство ЦПМ «Академия Бизнеса», Саратов 2019. - С. 48-50.

14. Хаққулов Н.Қ. Сиддиқий-Ажзийнинг ижтимоий-фалсафий қарашлари // Falsafa va Hayot | Философия и Жизнь // Philosophy and Life. - 2020. - №SI-2 Б. Б. 162-171. 